\title{
New Case of False-Star-Grass (Chloris distichophylla) Population Evolving Glyphosate Resistance
}

\author{
José G. Vázquez-García ${ }^{1}$, Sajedeh Golmohammadzadeh ${ }^{2}$, Candelario Palma-Bautista ${ }^{1}$, \\ Antonia M. Rojano-Delgado ${ }^{1} \mathbb{D}$, José A. Domínguez-Valenzuela ${ }^{3}$, Hugo E. Cruz-Hipólito ${ }^{1}$ and \\ Rafael De Prado ${ }^{1, *(D)}$ \\ 1 Department of Agricultural Chemistry and Edaphology, University of Cordoba, 14014 Córdoba, Spain; \\ z82vagaj@uco.es (J.G.V.-G.); z82pabac@uco.es (C.P.-B.); q92rodea@uco.es (A.M.R.-D.); \\ cruzhipolito@yahoo.com.mx (H.E.C.-H.) \\ 2 Department of Agronomy, Gorgan University of Agricultural Sciences and Natural Resources, \\ Gorgan 4918943464,Iran; sa_gmz@yahoo.com \\ 3 Department of Agricultural Parasitology, Chapingo Autonomous University, Texcoco 56230, Mexico; \\ jose_dv001@yahoo.com.mx \\ * Correspondence: qe1pramr@uco.es; Tel./Fax: +34-9572-186-00
}

Received: 7 February 2020; Accepted: 5 March 2020; Published: 9 March 2020

\begin{abstract}
Chloris distichophylla, suspected of glyphosate resistance (GR), was collected from areas of soybean cultivation in Rio Grande do Sul, Brazil. A comparison was made with a susceptible population (GS) to evaluate the resistance level, mechanisms involved, and control alternatives. Glyphosate doses required to reduce the dry weight $\left(\mathrm{GR}_{50}\right)$ or cause a mortality rate of $50 \%\left(\mathrm{LD}_{50}\right)$ were around 5.1-3 times greater in the GR population than in the GS population. The shikimic acid accumulation was around 6.2-fold greater in GS plants than in GR plants. No metabolized glyphosate was found in either GR or GS plants. Both populations did not differ in the enzyme 5-enolpyruvylshikimate-3-phosphate synthase (EPSPS) basal activity or in vitro inhibition of EPSPS activity by glyphosate $\left(\mathrm{I}_{50}\right)$. The maximum glyphosate absorption was observed at 96 hours after treatment (HAT), which was twofold higher in the GS plants than in the GR plants. This confirms the first case of glyphosate resistance in C. distichophylla. In addition, at $96 \mathrm{HAT}$, the GS plants translocated more ${ }^{14} \mathrm{C}$-glyphosate than the GR ones. The best options for the chemical control of both C. distichophylla populations were clethodim, quizalofop, paraquat, glufosinate, tembotrione, diuron, and atrazine. The first case of glyphosate resistance in C. distichophylla was due to impaired uptake and translocation. Chemical control using multiple herbicides with different modes of action (MOA) could be a tool used for integrated weed management (IWM) programs.
\end{abstract}

Keywords: glyphosate resistance; C. distichophylla; resistance mechanisms; chemical control

\section{Introduction}

Agricultural crops are exposed to environmental factors that influence their growth, development, and productivity [1]. The genus Chloris is poorly known and includes numerous weed species that are distributed across multiple continents in both tropical and subtropical regions. Many species of this genus are native to Argentina (C. elata and C. virgata), Brazil (C. elata and C. polydactyla), the Caribbean Islands and Mexico (C. elata, C. barbata, and C. ciliata), and Colombia (C. radiata) [2-6]. Among Chloris species, Chloris distichophylla Lag. [synonym: Eustachys distichophylla (Lag.) Nees], commonly known as false-star-grass or weeping fingergrass, is found in areas where soybean and fruit crops are grown in southern Brazil [7]. Losses in soybean productivity can reach a 70\% decrease when the soybean competes with Chloris polydactila, confirming the need to control the species of the same genus [8]. 
In addition, the genus Chloris species is the main focus of many farms, since it is naturally tolerant of glyphosate herbicide [8-11]. Authors, such as Nunes et al. [7] and Moraes de Aguiar et al. [8], report concerns about the presence of $C$. distichophylla and its ability to spread to other crops where they survive from glyphosate herbicide applications.

The use of herbicides is the most common weed control method. However, resistance to herbicides has reduced their effectiveness and commercial use for weed control. This is the result of evolutionary adaptations of weeds to the repeated application of a group of herbicides with the same mode of action (MOA), without the use of another alternative control [12]. Worldwide, glyphosate is one of the most common herbicides used during post-emergence owing to its simple, inexpensive, flexible, and effective control of monocotyledonous and dicotyledonous weeds in glyphosate-resistant (GRCs) and perennial crops [13-15]. This systemic and nonselective herbicide used during post-emergence inhibits the enzyme 5-enolpyruvylshikimate-3-phosphate synthase (EPSPS), which triggers a reaction between shikimate-3-phosphate and phosphoenolpyruvate to form 5-enolpyruvylshikimate-3-phosphate, an important step in the biosynthesis of aromatic amino acids in plants $[16,17]$. There are weed species that have the inherent ability to survive and reproduce after herbicide treatment. This implies that there is no selection or genetic manipulation to make the plant tolerant; it is naturally tolerant. On the other hand, resistance is the inherited ability of a plant (biotype) to survive and reproduce following exposure to an herbicide dose which is normally lethal to the wild type $[9,18]$. The survival of weeds after repeated applications of glyphosate (as the only control tool) for more than 10 consecutive years triggers evolutionary adaptations resulting in glyphosate resistance [19,20]. Currently, 48 species of glyphosate-resistant weeds have been confirmed [21], of which four belong to the genus Chloris. Most glyphosate-resistant Chloris species have been detected in Australia [22,23], Brazil [24,25], Cuba and the Dominican Republic [10], and Mexico [11].

Glyphosate resistance in weeds includes two different mechanisms: (1) outside the site of action, called NTSR (non-target-site resistance), which plays an important role in the differences between the absorption, translocation, and vacuole sequestration of the glyphosate applied to resistant (GR) and sensitive (GS) populations of the same species $[10,26,27]$ and (2) involved in protein binding (EPSPS), called TSR (target-site resistance), where the important role is played by the EPSPS, where target-site alterations are due to target-site mutations $[10,23]$ or target-site gene amplifications $[22,28]$ in glyphosate-resistant populations.

The objective of this work was to characterize glyphosate-resistant $C$. distichophylla in southern Brazil. This was conducted to (1) assess the resistance levels between a GR and GS population, (2) determine the NTSR or TSR mechanisms involved, and (3) seek alternatives for the chemical control of both populations.

\section{Materials and Methods}

\subsection{Chemicals}

C. distichophylla plants were sprayed with commercially formulated glyphosate. Analytical grade (>99.5\%) glyphosate was used to determine the effects of the herbicide on the biochemical and molecular aspects of the plants. ${ }^{14} \mathrm{C}$-glyphosate (glycine-2- ${ }^{14} \mathrm{C}$ ), with a radiochemical purity of $95 \%$ and specific activity $273.8 \mathrm{MBq} \mathrm{mmol}^{-1}$, was obtained from the Institute of Isotopes Co., Ltd. (Budapest, Hungary).

\subsection{Plant Materials}

C. distichophylla seeds were collected from areas of soybean cultivation in Rio Grande do Sul, Brazil, where the control of this weed was very poor after the application of glyphosate at a rate of $720 \mathrm{~g}_{\text {ae }} \mathrm{ha}^{-1}$ [7].

In 2017 , seeds were sown in trays $(15 \times 15 \times 8 \mathrm{~cm})$ with a peat substrate that had been moistened to field conditions, before being covered with parafilm. The trays were taken to a growth chamber calibrated at $28 / 18{ }^{\circ} \mathrm{C}$ day/night, with a $16 \mathrm{~h}$ photoperiod, at a light intensity of $850 \mu \mathrm{mol}^{-2} \mathrm{~s}^{-1}$, and at 
$60 \%$ relative humidity. The seedlings were transplanted into $3 \mathrm{~L}$ pots $(5$ plants per pot) containing a mixture of sand/peat $(1: 1 \mathrm{v} / \mathrm{v})$, before placing them back into the growth chamber. They were watered daily until the start of the glyphosate treatments [11].

The first screening test was conducted on the GR populations to eliminate susceptible individuals from the seeds (population homogenization). Twenty pots (5 plants/pots), containing plants with 3-4 true leaves, were treated with glyphosate at a rate of $720 \mathrm{~g}$ ae ha ${ }^{-1}$ (Roundup Energy $45 \%$ w/v, Monsanto, Madrid, Spain) using a laboratory chamber (SBS-060 De Vries Manufacturing, MN, Hollandale) equipped with an 8002 flat fan nozzle that delivers $200 \mathrm{~L} \mathrm{ha}^{-1}$, at $250 \mathrm{KPa}$ at a height of $50 \mathrm{~cm}$. Surviving individuals $(\sim 80 \%)$ were grown to maturity, bulked, and allowed to produce seeds.

A second screening test was conducted on the GR population to improve the resistance level, repeating the first experiment but with glyphosate at a rate of $1080 \mathrm{~g}$ ae ha ${ }^{-1}$ (field doses used in Spain). Finally, the surviving plants ( $>90 \%$ ) were grown to maturity, bulked, and allowed to produce seeds. For comparison, seeds of a nontreated population (referred to as GS) were harvested in a nearby area that had never been treated with herbicides. During the first screening test, the susceptible seeds were germinated and the transplant plants with 3-4 leaves were treated with glyphosate at a rate of $550 \mathrm{~g}$ ae $\mathrm{ha}^{-1}$. However, two weeks after treatment, all susceptible plants died.

In the tests conducted during 2019, GR and GS populations with a germination percentage higher than $80 \%$ were used to confirm the resistance of $C$. distichophylla to glyphosate.

\subsection{Dose-Response Assay with Glyphosate}

GR and GS C. distichophylla populations were sprayed with the following increasing doses of glyphosate: $0,31.25,62.5,125,250,500,1000,1500$, and $2000 \mathrm{~g}$ ae ha ${ }^{-1}$ (10 replicates per dose) in the treatment chamber. Four weeks after treatment (WAT), the survival (plants were considered dead if they showed no active growth) was assessed and the shoots of the aerial part of the plants (dried at $60{ }^{\circ} \mathrm{C}$ for 4 days) were harvested and weighed. Data are expressed as percentages. The experiment was repeated twice, once during spring and once during fall.

\subsection{Shikimic Acid Accumulation Assay}

The shikimic acid accumulation was studied following the methodology described by Shaner et al. [29] with some modifications which will be detailed below. Young leaf tissue samples (50 $\mathrm{mg}$ in $4 \mathrm{~mm}$ leaf discs) were taken and placed in Eppendorf tubes $(2 \mathrm{~mL})$ which contained $1 \mathrm{~mL}$ of monoammonium phosphate $\left(\mathrm{NH}_{4} \mathrm{H}_{2} \mathrm{PO}_{4} 10 \mathrm{mM}, \mathrm{pH} 4.4\right)$ plus glyphosate solutions at different concentrations $(0,100,200$, $400,800$, and $1000 \mu \mathrm{M})$. The samples were incubated for $24 \mathrm{~h}$ under fluorescent light $\left(150 \mu \mathrm{M} \mathrm{m}^{-2} \mathrm{~s}^{-1}\right)$. After this time, the samples were frozen until their analysis. The process followed incubating these frozen samples at $60^{\circ} \mathrm{C}$ for $30 \mathrm{~min}$. A $250 \mu \mathrm{L}$ amount of hydrochloric acid $(\mathrm{HCl} 1.25 \mathrm{~N})$ was added and incubated at $60^{\circ} \mathrm{C}$ for $15 \mathrm{~min}$. Aliquots of $250 \mu \mathrm{L}$ were transferred to new Eppendorf tubes $(1.5 \mathrm{~mL})$ and $500 \mu \mathrm{L}$ of periodic acid $(0.25 \% \mathrm{w} / \mathrm{v})$ and sodium metaperiodate $(0.25 \% \mathrm{w} / \mathrm{v})$ solution were added in proportion $(1: 1(\mathrm{v} / \mathrm{v}))$. The samples were incubated at $25^{\circ} \mathrm{C}$ for $90 \mathrm{~min}$. Next, $500 \mu \mathrm{L}$ of a mix of sodium hydroxide $(\mathrm{NaOH} 0.6 \mathrm{~N})$ and sodium sulfite $\left(\mathrm{Na}_{2} \mathrm{SO}_{3} 0.22 \mathrm{~N}\right)$ in a 1:1 ratio was added and mixed. Sample absorbance was measured using a spectrophotometer (model DU-640, Beckman Instruments Inc., Fullerton, USA) at $380 \mathrm{~nm}$. The experiment had a completely randomized design, using three tissue samples from each GR and GS C. distichophylla population per glyphosate concentration. The absorbance results were expressed as micrograms shikimate per milliliter HCL solution $(\mu \mathrm{g} / \mathrm{mL})$ using a calibration curve with known concentrations of shikimate. The experiment was repeated twice.

\subsection{Absorption and Translocation}

${ }^{14}$ C-glyphosate + commercial glyphosate solution was applied to GR and GS C. distichophylla plants. The final glyphosate concentration corresponded to $360 \mathrm{~g}$ ae ha ${ }^{-1}$ in $200 \mathrm{~L} \mathrm{ha}^{-1}$, which contained

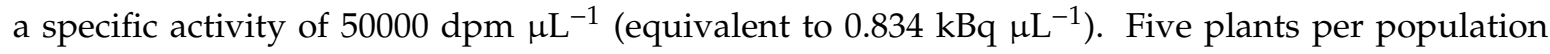


were treated with one drop $\left(1 \mu \mathrm{L}\right.$ plant $\left.^{-1}\right)$ of the solution on the adaxial surface of the first or second leaf. After treatment, the plants were maintained in the growth chamber at the growing conditions described in the plant material section. The nonabsorbed ${ }^{14} \mathrm{C}$-glyphosate was removed from the treated leaves (at 12, 24, 48, 72, and 96 hours after treatment (HAT)) by washing them three times separately with $1 \mathrm{~mL}$ of a water-acetone solution $(1: 1 \mathrm{v} / \mathrm{v})$ each time. The washing solution was mixed with $2 \mathrm{~mL}$ of scintillation liquid (Ultima Gold, Perkin-Elmer, BV BioScience Packard, MA, USA) and analyzed by liquid scintillation spectrometry (LSS) using a scintillation counter model (LS 6500, Beckman Coulter Inc., Fullerton, CA, USA) with reading time of 10 min per sample. After washing, whole plants were removed from the pot and sectioned into treated leaves, the remainder of the shoot, and roots (this plant section was carefully washed with distilled water and excess moisture removed with paper towel). The samples were stored in cellulose cones (Perkin-Elmer, BV BioScience Packard, MA, USA), dried in an oven at $60^{\circ} \mathrm{C}$ for $96 \mathrm{~h}$, and combusted in a biological oxidizer (Packard Tri Carb 307, Packard Instrument Co., Downers Grove, IL, USA). The $\mathrm{CO}_{2}$ released from the combustion was captured in $18 \mathrm{~mL}$ of a mix of Carbo-Sorb E and Permafluor (1:1 (v/v)) (Perkin-Elmer, BV BioScience Packard, MA, USA). The radioactivity of each individual sample was quantified by LSS over $10 \mathrm{~min}$ per sample. The percentages of ${ }^{14} \mathrm{C}$-glyphosate recovered, absorbed, and translocated were calculated using the radioactive values in $\mathrm{dpm}$. The equipment efficiency correction factor was calculated to be $90 \%$. To visualize the translocation of ${ }^{14} \mathrm{C}$-glyphosate, three plants were treated under the same conditions as in the previous assay. At $96 \mathrm{HAT}$, plants were washed individually, fixed on filter paper, and dried at $25^{\circ} \mathrm{C}$ (room temperature) for one week. The plants were pressed for $4 \mathrm{~h}$ under a phosphor store film (Storage Phosphor System: Cyclone, Perkin-Elmer Packard BioScience BV, MA, USA) and visualized using a phosphor imager Cyclone (Perkin-Elmer, Packard BioScience BV, MA, USA).

\subsection{Metabolism Study}

Glyphosate (300 $\mathrm{g}_{\text {a }} \mathrm{ha}^{-1}$ ), in a completely randomized design, was applied to GR and GS C. distichophylla plants with 3-4 leaves. Plants not treated with the herbicide were used as a control. After 96 hours, the treated plants were washed with distilled water and flash-frozen in liquid nitrogen. The glyphosate and its metabolites (AMPA, glyoxylate, formaldehyde, and sarcosine) were determined following the methodology described by Rojano-Delgado et al. [30] via reversed polarity capillary electrophoresis, using a 3D Capillary Electrophoresis Agilent G1600A instrument (Agilent Technologies, Inc., Santa Clara, CA, USA) equipped with a diode array detector (DAD) with a wavelength range of 190-600 nm. The background electrolyte was composed of $10 \%$ ACN, $7.5 \mathrm{mM}$ phthalate, and $0.75 \mathrm{mM}$ hexadecyltrimethylammonium, and the applied voltage was $-20 \mathrm{kV}$. The glyphosate and its metabolite concentrations were determined using standard equations. The natural glyoxylate produced by untreated plants was subtracted from the glyoxylate metabolism of treated plants [10,31,32]. The experiment was repeated twice.

\subsection{EPSPS Enzyme Activity Assay}

Young foliar tissue samples $(5 \mathrm{~g})$ were taken from each population. Samples were ground to a fine powder in liquid nitrogen using a chilled mortar. Enzyme extraction was performed following the protocol described by Sammons and Gaines [20]. The specific EPSPS activity was assayed in the presence of glyphosate $(0,0.1,1,10,100$, and $1000 \mu \mathrm{M})$ using the EnzChek Phosphate Assay Kit (Invitrogen, Carlsbad, CA, USA). The EPSPS enzyme reaction substrates were phosphoenolpyruvate and shikimate-3-phosphate, which were supplied by Sigma-Aldrich (Madrid, Spain). The release of phosphate was measured for $10 \mathrm{~min}$ at $360 \mathrm{~nm}$ in a spectrophotometer (model DU-640, Beckman Instruments Inc., Fullerton, USA). The total soluble protein (TSP) in the extract was measured using a Kit for Protein Determination (Sigma-Aldrich, Madrid, Spain), following the manufacturer's instructions. The EPSPS activity was measured for $10 \mathrm{~min}$ at $360 \mathrm{~nm}$ in a spectrophotometer (model DU-640) to determine the amount of inorganic phosphate $(\mu \mathrm{mol})$ released per $\mu \mathrm{g}$ of total soluble protein (TSP) per $\min \left(\mu \mathrm{mol} \mathrm{Pi} \mu \mathrm{g}^{-1} \mathrm{TSP} \mathrm{min}^{-1}\right)$. The EPSPS activity is expressed as a percentage relative to the control 
(absence of glyphosate). Three technical replications of each glyphosate concentration were analyzed per population. The experiment was repeated twice.

\subsection{Assay with Alternative Herbicides}

To evaluate the potential efficacy of an integrated weed management (IWM) program and screening for multiple herbicide resistances, alternative herbicides were applied (with the same conditions and spraying volume as the previous assay) on the GR and GS populations of $C$. distichophylla. The different herbicides and doses that were used are shown in Table 1. Plants were cut 28 days after the treatment (DAT), after which visual evaluations were conducted and the fresh weight reduction values of the plants were determined. Treatments were replicated three times in a completely randomized design, using 10 plants per dose and population. The experiment was repeated twice, once during spring and once during fall.

Table 1. Herbicides, active ingredients, mode of action (MOA), and dose (in $\mathrm{g}$ ai ha ${ }^{-1}$ ) applied on $C$. distichophylla populations.

\begin{tabular}{cccc}
\hline Trade Name & Active Ingredient & MOA $^{\mathbf{a}}$ & $\begin{array}{c}\text { Field Dose } \\
\text { (g ai ha-1) }\end{array}$ \\
\hline Control & - & - & - \\
Centurion Plus 12\% & Clethodim & ACCase & 100 \\
Leopard 5\% & Quizalofop & ACCase & 100 \\
Hussar 5\% & Iodosulfuron & ALS & 5 \\
Terafit 25\% & Flazasulfuron & ALS & 50 \\
Paratex 20\% & Paraquat & PS I & 400 \\
Goal Supreme 24\% & Oxyfluorfen & PPO & 500 \\
Finale 15\% & Glufosinate & GS & 500 \\
Laudis 20\% & Tembotrione & HPPD & 120 \\
Diuron $80 \%$ & Diuron & PS II & 1800 \\
Atazinax-Flo $47.5 \%$ & Atrazine & PS II & 2000 \\
\hline
\end{tabular}

a Abbreviations: acetyl CoA carboxylase (ACCase); acetolactate synthase (ALS); Photosystem I-electron diversion (PS I); protoporphyrinogen oxidase (PPO); glutamine synthetase (GS); 4-hydroxyphenylpyruvate dioxygenase (HPPD); Photosystem II (PS II).

\subsection{Statistical Analysis}

The data (percentages) concerning the weight reduction, survival, and EPSPS enzyme activity were subjected to a nonlinear regression analysis to decipher the amount of glyphosate needed to reduce the dry weight $\left(\mathrm{GR}_{50}\right)$, cause mortality $\left(\mathrm{LD}_{50}\right)$, and inhibit the EPSPS activity $\left(\mathrm{I}_{50}\right)$ by $50 \%$, respectively. The log-logistic equation (1) used is as follows:

$$
y=c+\left\{(d-c) /\left[1+(x / g)^{\mathrm{b}}\right]\right\}
$$

where $Y$ is the percentage of the dry weight, mortality, and/or EPSPS enzyme inhibited, relative to the control; $c$ and $d$ are the lower and upper limits of the curve, respectively; $b$ is the slope at the inflection point (i.e., $\mathrm{GR}_{50}, \mathrm{LD}_{50}$, or $\mathrm{I}_{50}$ ); and $x$ is the glyphosate dose. The regression analyses were conducted using the $d r c$ package with program $\mathrm{R}[33,34]$. Resistance factors $(\mathrm{RF}=\mathrm{GR} / \mathrm{GS})$ were computed as GR-to-GS GR $\mathrm{G}_{50}$, $\mathrm{LD}_{50}$, or $\mathrm{I}_{50}$ ratios.

Data concerning the shikimic acid, basal EPSPS activity, uptake, translocation, metabolism, and alternative control assay were subjected to an ANOVA using the Statistix (version 10.0) (Analytical software, Tallahassee, FL, USA) software. The model assumptions of a normal error distribution and homogeneous variance were graphically inspected. Differences with $p<0.05$ were considered significant and a Tukey's test was conducted to compare the means. 


\section{Results}

\subsection{Dose-Response Assay with Glyphosate}

The dose-response assay showed differences in the $\mathrm{GR}_{50}$ and $\mathrm{LD}_{50}$ values of the GS and GR C. distichophylla populations (Table 2). The plant survival and dry weight decreased as the glyphosate dose increased. For the GR population, the glyphosate doses required to reduce the dry weight $\left(\mathrm{GR}_{50}\right)$ and kill the plant population $\left(\mathrm{LD}_{50}\right)$ by $50 \%$ were 730.10 and $1526.60 \mathrm{~g}$ ae ha ${ }^{-1}$, respectively. The GR population had a resistance factor (RF) value of 5.10. The $\mathrm{LD}_{50}$ value of the GR population exhibited a 2.95-fold resistance when compared with the GS population (Figure 1).

Table 2. Parameters of the log-logistic equations ${ }^{\mathrm{a}}$ used to calculate the glyphosate rates $\left(\mathrm{g}_{\mathrm{ge} \mathrm{ha}}{ }^{-1}\right)$ required for $50 \%$ survival $\left(\mathrm{LD}_{50}\right)$ or a $50 \%$ reduction in the dry weight $\left(\mathrm{GR}_{50}\right)$ of $C$. distichophylla populations.

\begin{tabular}{|c|c|c|c|c|c|}
\hline \multirow[b]{2}{*}{ Population } & \multicolumn{5}{|c|}{ Plant Survival $\left(\mathrm{LD}_{50}\right)$} \\
\hline & d (SE) & $\mathbf{b}(\mathrm{SE})$ & $\mathrm{LD}_{50}(\mathrm{SE})$ & $P$ & RF \\
\hline GS & $100.00 \pm 0.04$ & $11.81 \pm 1.33$ & $517.82 \pm 2.00$ & $<0.0001$ & - \\
\hline \multirow[t]{3}{*}{ GR } & $100.04 \pm 0.04$ & $23.02 \pm 0.72$ & $1526.6 \pm 0.85$ & $<0.0001$ & 2.95 \\
\hline & \multicolumn{5}{|c|}{ Growth Reduction $\left(G R_{50}\right)$} \\
\hline & d (SE) & b (SE) & $\mathrm{GR}_{50}(\mathrm{SE})$ & $P$ & RF \\
\hline GS & $97.04 \pm 2.23$ & $2.26 \pm 0.21$ & $142.95 \pm 6.99$ & $<0.0001$ & - \\
\hline GR & $95.47 \pm 1.48$ & $2.35 \pm 0.19$ & $730.10 \pm 33.36$ & $<0.0001$ & 5.10 \\
\hline
\end{tabular}

a $d$ is upper limits of the curve; $b$ is the slope at the inflection point (i.e., $\mathrm{GR}_{50}, \mathrm{LD}_{50}$ ); $\mathrm{SE} \pm$ is the standard errors of the means; $P$ is the level of significance of the non-linear model, and RF, resistance factor (GR/GS) calculated using $\mathrm{LD}_{50}$ or $\mathrm{GR}_{50}$ of de respective population.

A

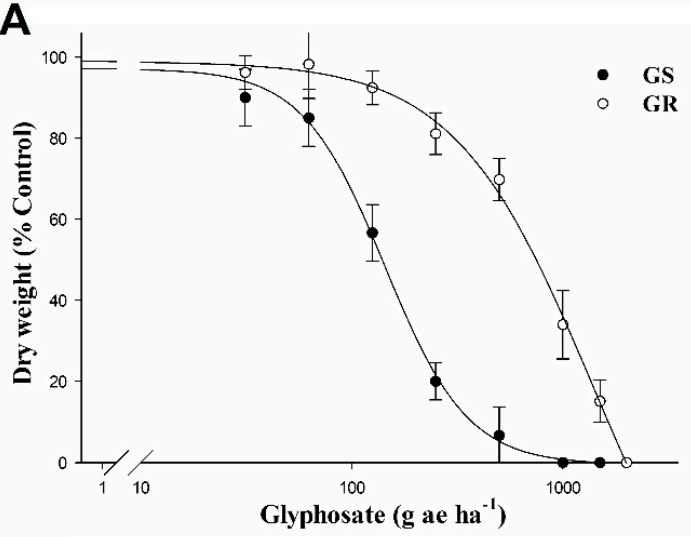

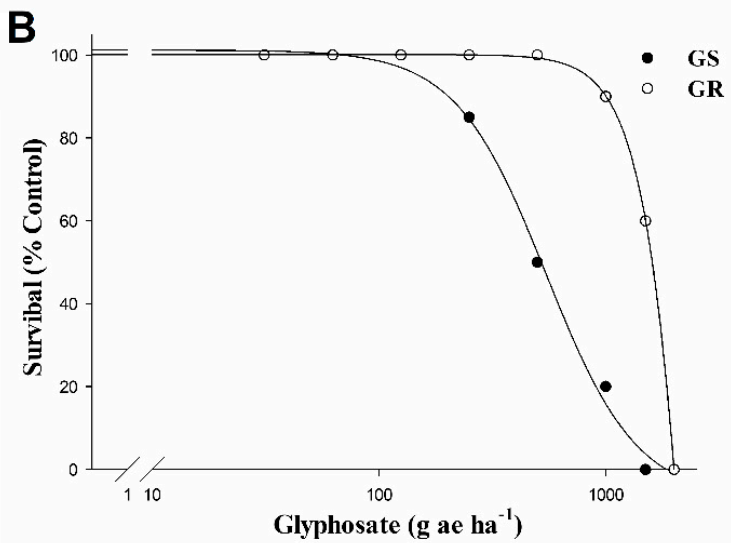

Figure 1. Effects of the glyphosate dose on the dry weight reduction (A) and plant survival (B) of the untreated (control) C. distichophylla GS $(\bullet)$ and GR $(\bigcirc)$ populations, expressed as a percentage of the mean $(n=10) \pm \mathrm{SE}$.

\subsection{Shikimic Acid Accumulation Assay}

The shikimic acid (sk) accumulation patterns in the glyphosate-exposed leaves of the two C. distichophylla populations are shown in Figure 2. In agreement with the contrasting responses of GR and GS populations to glyphosate doses, the leaves of GS plants accumulated greater quantities of shikimate compared to those of GR plants. From 100 to $1000 \mu \mathrm{M}$ of glyphosate, the accumulation of shikimic acid increased slightly in both populations. Across the different glyphosate doses, the accumulation of shikimic acid ranged from 13.20 to $291.20 \mu \mathrm{g} \mathrm{sk} \mathrm{g}^{-1}$ of fresh weight in the GS population when compared with 11.68 to $46.80 \mu \mathrm{g} \mathrm{sk} \mathrm{g}^{-1}$ of fresh weight in the GR population. At $1000 \mathrm{mM}$ of glyphosate, the highest concentration tested, the difference was 6.22-fold greater in GS versus GR leaf segments. 


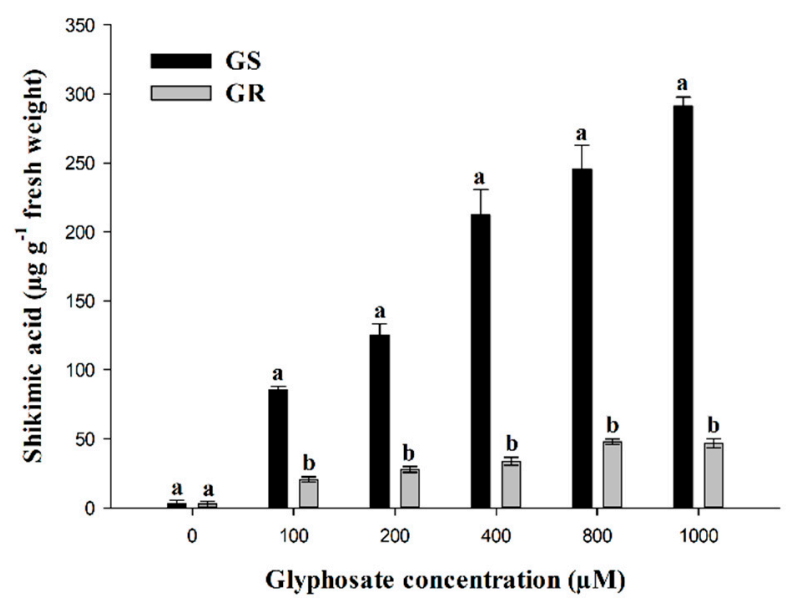

Figure 2. Shikimic acid accumulation in plant leaves of susceptible (GS) and resistant (GR) C. distichophylla populations. Symbols denote the means $(n=3)$, vertical bars correspond to standard errors of the mean.

\subsection{Absorption and Translocation}

${ }^{14} \mathrm{C}$-glyphosate absorption in the GR population increased slowly until 72 HAT. At this time, the GS population had absorbed $48.32 \%$ of the glyphosate, while the GR population had only absorbed $23.32 \%$. The maximum glyphosate absorption rate was observed after $72 \mathrm{HAT}$, which was twofold higher in the GS population than in the GR population (Figure 3). Compared with the GR plants, the GS plants moved more ${ }^{14} \mathrm{C}$ from the treated leaves to the rest of the plant and roots. The quantitative translocation results showed that in the GR plants, $83 \%$ of the glyphosate was retained in the treated leaves, while in the GS plants, only $42 \%$ was retained. Thus, the proportion of ${ }^{14} \mathrm{C}$-glyphosate translocated to the rest of the plant and roots was $29.2 \%$ and $28.6 \%$ in GS plants, respectively, while in GR plants, it was $10 \%$ and $6.32 \%$, respectively (Table 3 ).

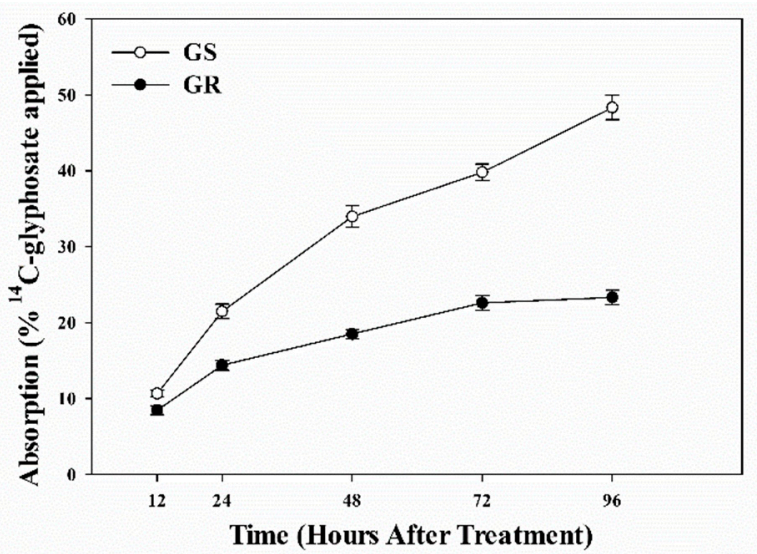

Figure 3. Absorption of glyphosate in susceptible (GS) and resistant (GR) populations of C. distichophylla. Symbols denoted are the $(n=5)$ standard errors of the mean. 
Table 3. Radiolabel translocation from the treated leaves in the resistant (GR) and susceptible (GS) populations of $C$. distichophylla 96 hours after treatment with ${ }^{14} \mathrm{C}$-glyphosate.

\begin{tabular}{ccccc}
\hline \multirow{2}{*}{ Population } & \multirow{2}{*}{ \% Absorption } & \multicolumn{3}{c}{ Translocation (\% of Absorbed) } \\
\cline { 3 - 5 } & & Treated Leaf & Rest of Plant & Roots \\
\hline GS & $48.32 \pm 1.60 \mathrm{a}$ & $42.22 \pm 2.35 \mathrm{~b}$ & $29.2 \pm 0.73 \mathrm{a}$ & $28.6 \pm 2.82 \mathrm{a}$ \\
\hline GR & $23.32 \pm 0.93 \mathrm{~b}$ & $83 \pm 2.09 \mathrm{a}$ & $10.68 \pm 0.40 \mathrm{~b}$ & $6.32 \pm 2.06 \mathrm{~b}$ \\
\hline
\end{tabular}

Means in the same row followed by the same letter are not significantly different at $p<0.05$. Mean values \pm standard error of the mean.

\subsection{C-glyphosate Visualization}

Using a phosphor imaging system, we were able to visualize the distribution of ${ }^{14} \mathrm{C}$-glyphosate in both GR and GS populations of $C$. distichophylla (Supplementary Materials). Clearly, a higher ${ }^{14} \mathrm{C}$-glyphosate uptake and translocation was observed in the GS population compared with the GR population. This qualitative distribution of glyphosate is in accordance with the quantitative results obtained from the oxidation of ${ }^{14} \mathrm{C}$-glyphosate 96 HAT (Table 3).

\subsection{Metabolism Study}

The metabolism assays showed that glyphosate was poorly metabolized to nontoxic compounds in both the GS and GR populations of C. distichophylla. Quantitatively, $96.13 \%$ and $95.67 \%$ of glyphosate was maintained in the GS and GR plant populations, respectively. The levels of AMPA metabolized to nontoxic products (glyoxylate and sarcosine) were undetectable in both the GS and GR populations (data not shown).

\subsection{EPSPS Enzyme Activity Assay}

The concentration of glyphosate required to inhibit the EPSPS activity by $50 \%$ ( $\left.\mathrm{I}_{50}\right)$ was 11.9 and $12.3 \mu \mathrm{M}$ in the GS and GR populations, respectively, with no significant difference between the two (Figure 4). In addition, the EPSPS activity in the absence of glyphosate was similar in the GS and

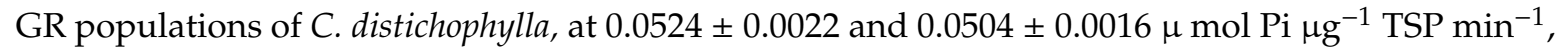
respectively. Increased EPSPS enzyme activity is a plausible TSR mechanism for glyphosate resistance. However, no differences were apparent between the GS and GR plants for either the EPSPS activity in the absence of glyphosate or the inhibition response to glyphosate $\left(\mathrm{I}_{50}\right)$.

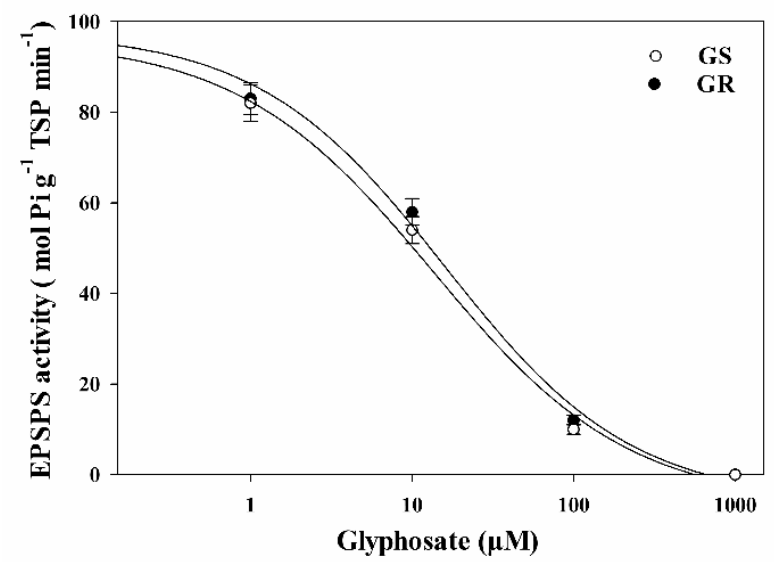

Figure 4. Dose-response curves of the EPSPS enzyme activity of $C$. distichophylla plants exposed to different glyphosate concentrations $(\mu \mathrm{M})$, expressed as a percentage of the untreated control $(n=3)$. 


\subsection{Assay with Alternative Herbicides}

C. distichophylla has been shown to be resistant to glyphosate. The use of other herbicides, with different modes of action, to control this glyphosate resistance was seemingly possible. Both GS and GR populations had chlorosis 1 DAT with paraquat, 3 DAT with oxyfluorfen and tembotrione, and between 6 and 7 DAT with glufosinate. The action of paraquat was so fast and effective that within the first 7 DAT, the plants were dead (Table 4). Oxyfluorfen applied during the early post-emergence of 3-4 leaves lost efficacy with respect to pre-emergence applications (data not shown), with between $50 \%$ and $70 \%$ of the plants surviving 28 DAT, which is not acceptable to farmers. The herbicides atrazine and diuron (PS II inhibitors) and grass weed herbicides, such as clethodim and quizalofop, had phytotoxic effects that began to be visible 10 DAT. However, their control was $100 \%$ in both the GS and GR populations at 28 DAT. The two sulfonylureas (ALS inhibitors) used had a low efficacy, with plant survival at $100 \%$ and a reduction in the growth at the end of the experiment that was not acceptable (Table 4).

Table 4. Alternative herbicides used to control C. distichophylla GR and GS populations after 28 DAT, visual evaluation, survival plant, and fresh weight $(\mathrm{Fw})$ reduction.

\begin{tabular}{cccccccc}
\hline \multirow{2}{*}{ Herbicides } & \multirow{2}{*}{ MOA } & \multicolumn{2}{c}{ Visual Evaluation $^{\mathbf{a}}$} & \multicolumn{2}{c}{ \% Survival Plant $^{\mathbf{b}}$} & \multicolumn{2}{c}{ \% Fw Reduction $^{\mathbf{c}}$} \\
\cline { 3 - 7 } & & GS & GR & GS & GR & GS & GR \\
\hline Control & - & 0 & 0 & 100 & 100 & $0 \mathrm{~d}$ & $0 \mathrm{~d}$ \\
Clethodim & ACCase & 100 & 100 & 0 & 0 & $100 \mathrm{a}$ & $100 \mathrm{a}$ \\
Quizalofop & ACCase & 100 & 100 & 0 & 0 & $100 \mathrm{a}$ & $100 \mathrm{a}$ \\
Iodosulfuron & ALS & 0 & 0 & 100 & 100 & $18 \mathrm{c}$ & $15.63 \mathrm{c}$ \\
Flazasulfuron & ALS & 70 & 70 & 100 & 100 & $41 \mathrm{~b}$ & $37.5 \mathrm{~b}$ \\
Paraquat & PS I & 100 & 100 & 0 & 0 & $100 \mathrm{a}$ & $100 \mathrm{a}$ \\
Oxyfluorfen & PPO & 90 & 90 & 50 & 75 & $40 \mathrm{~b}$ & $42.5 \mathrm{~b}$ \\
Glufosinate & GS & 100 & 100 & 0 & 0 & $100 \mathrm{a}$ & $100 \mathrm{a}$ \\
Tembotrione & HPPD & 100 & 100 & 0 & 0 & $100 \mathrm{a}$ & $100 \mathrm{a}$ \\
Diuron & PS II & 100 & 100 & 0 & 0 & $100 \mathrm{a}$ & $100 \mathrm{a}$ \\
Atrazine & PS II & 100 & 100 & 0 & 0 & $100 \mathrm{a}$ & $100 \mathrm{a}$ \\
\hline
\end{tabular}

${ }^{a}$ The visual evaluation was based on the vigor and chlorosis of the plant, compared to the control, with $0 \%$ attributed when there was no injury and $100 \%$ when there was total control of the plants by the herbicides. ${ }^{\mathrm{b}}$ Control was considered unsatisfactory when the survival of the plants was greater than or equal to $85 \%$, and satisfactory when less than $15 \% .{ }^{c}$ Means with different letter within a column are statistically different at $95 \%$ probability determined by the Tukey's test.

\section{Discussion}

Brazil, the world's second largest producer of soybean and third largest for corn, is firmly attached to the use of herbicides, particularly those that are glyphosate-based, which have allowed them to adopt a direct sowing system and become competitive in the world agricultural market. Currently, $90 \%$ of the area is planted with glyphosate-resistant soybean. It is estimated that the biggest problems with resistant weeds are in southern Brazil, although it is difficult to affirm these percentages exactly [35]. Glyphosate was introduced in 1974 and presented no weed resistance problems until 1995, when a population of resistant Lolium rigidum was detected in Australia [36]. The intense use of glyphosate contributed to the diffusion of weeds with resistance and/or tolerance to this herbicide in Brazil, including species such as Conyza bonariensis, Conyza canadensis, Coniza sumatrensis, Lolium multiflorum, Digitaria insularis, Amaranthus palmeri, Chloris elata, C. polydactyla, and Eleusine indica [21]. The appearance of a new resistant species such as $C$. distichophylla demonstrates the difficulty that farmers face due to a lack of knowledge and tools that are as effective as glyphosate available to combat the serious problem of resistance in Brazil. Studies conducted by Nunes et al. [7] and Moraes de Aguiar et al. [8] showed that $C$. distichophylla had been selected in areas treated with glyphosate, due to its possible natural tolerance. Nevertheless, there have been reports confirming resistance levels or 
mechanisms involved that classify it as resistant or tolerant, which is a function of whether there is a population considered susceptible.

The first case of resistance of $C$. distichophylla was based on the resistance factor $\left(\mathrm{GR}_{50} \mathrm{R} / \mathrm{GR}_{50} \mathrm{~S}\right)$ which must be greater than 4 , following the resistancedefinition [21]. In addition, the $\mathrm{LD}_{50}$ parameter was used to define the herbicide dose that was necessary to reduce the number of individuals in a population to $50 \%$. The field dose of glyphosate used in Brazil is $720 \mathrm{~g} \mathrm{ae} \mathrm{ha}^{-1}$, which was sufficient to fully control the GS population, but not the GR population of $C$. distichophylla (Table 2). From an agronomic perspective, referring to a resistant population by the $\mathrm{LD}_{50}$ value is quite subjective, since the dose used in the field varies according to the environmental conditions of each country [10,11,22-25]. In addition, the sensitivity of weed species to herbicides varies among species [37].

The leaf disc experiment may be affected by the ability of glyphosate to penetrate and move into the chloroplast or by the greater or lesser ability of the herbicide to bind to its EPSPS target site $[10,17,23]$. The shikimic acid accumulation was significantly higher in GS plants than GR plants, especially at the highest concentrations (Figure 2). The different levels of shikimic acid accumulation in GR and GS weeds have been accepted as a quick and easy indicator for determining the level of glyphosate resistance [29]. In our study, GS C. distichophylla plants showed 6.2 times more shikimate accumulation than GR plants, which agrees with previously obtained results in experiments using whole plants. However, these results do not allow us directly to conclude what kind of mechanisms are responsible for glyphosate resistance. Thus, we need to continue our research.

With the evolution of glyphosate-resistant weeds, one of the first research focuses has been a comparison of the absorption and/or translocation of glyphosate in GR and GS species using ${ }^{14}$ C-glyphosate $[11,22,23,25,27,31,38,39]$. Studies conducted on five Chloris species collected in Australia, Cuba, Mexico, and Brazil do not follow the same pattern. Two populations of C. elata harvested from Cuba and Brazil show differences in glyphosate absorption or translocation between GR and GS plants [10,25]. Nevertheless, C. truncate and C. virgata, originally from South Australia, exhibited no differences in glyphosate absorption or translocation between GR and GS plants [22,23]. Finally, a recently published new species of $C$. barbata collected in Colima state, Mexico, did not show any differences in ${ }^{14} \mathrm{C}$-glyphosate absorption between GR and GS populations, but the GR plants translocated less herbicide to the rest of plant and roots [11]. These results show that the patterns concerning the penetration and movement of glyphosate within different species of the same genus are not the same. In addition, these species, collected from crops in different countries, have different selection pressures due to the use of glyphosate, including both abiotic and biotic factors, which could cause these species to have different glyphosate resistance mechanisms.

Glyphosate metabolism has not been identified as a main mechanism of resistance in plants [20,40,41]. However, recently Powles's group has published that Echinochloa colona is able to metabolize glyphosate via aldo-keto reductase [42]. Only in a few cases has it been shown that metabolism is a secondary mechanism in glyphosate resistance (e.g., Cologania broussonetii [43], Ipomoea lacunosa [44], C canadensis [45], Digitaria insularis [31], and Parthenium hysterophorus [46], among others). Our research confirms that the absorbed glyphosate (>90\%) remains unmetabolized in the GR and GS plants (Table 3). This unmetabolized glyphosate makes it possible for C. distichophylla to decrease its EPSPS activity by inhibition in both populations (Figure 4). Given the small extent of glyphosate metabolism, the importance of this result is unlikely to be biologically significant for glyphosate resistance in this species.

Differences in the EPSPS enzyme activity could involve alterations in the gene that encodes the target protein $[20,23,47]$. However, the similar basal activities of the GR and GS C. distichophylla populations suggest that there was no EPSPS genetic amplification in the GR plants, despite this mechanism being characterized as the principal factor associated with resistance to glyphosate in other grasses [38]. In the absence of any differences in the EPSPS basal activity, similar values of $\mathrm{I}_{50}$ between both $C$. distichophylla and C. elata populations from Brazil reveal the nonexistence of 
mutations in the EPSPS gene coding [25]. However, in other species of the genus Chloris, mutations were found $[11,22,23]$.

Worldwide, C. distichophylla has never been reported as resistant to an herbicide. However, in addition to the results of our work, works such as that of Nunes et al. [7] have shown that the use of different herbicides, such as paraquat and atrazine, remains a good alternative in addition to glyphosate. Additionally, studies on other grasses such as Lolium multiflorum [48] have shown that the use of clethodim and diuron in conjunction with glyphosate is a potential control tool. Recent studies on glyphosate-resistant weeds such as Echinochloa colona and Chloris virgata [49] have shown that HPPD inhibitor herbicides, ACCase inhibitors, and photosystem I and II inhibitors have been highly effective for control when used together. Our work shows that, for now, herbicides are good alternatives for the control of $C$. distichophylla. ALS inhibitor herbicides such as iodosulfuron are products that work best when applied in an admixture with other products, not individually. Conversely, flazasulfuron is an herbicide that acts considerably better when used during pre-emergence or early post-emergence [50]. From the results obtained in other countries after the excessive use of glyphosate, where they adopt strategies with and without the use of herbicides, it is clear that the only way to combat resistance is the use of herbicides with different mechanisms of action [50].

\section{Conclusions}

The continuous application of glyphosate increases the tolerance and promotes selection for resistance in C. distichophylla. Our study confirmed the first case of glyphosate resistance in C. distichophylla; this resistance was due to impaired uptake and translocation of glyphosate in the evaluated population. Chemical control with different MOA herbicides could be one option for an IWM program. The best chemical controls for both $C$. distichophylla populations were ACCase (quizalofop and clethodim), GS (glufosinate), PS I (paraquat), PS II (diuron and atrazine), and HPPD (tembotrione) inhibitor herbicides. The idea that nonchemical controls could be used for the control of this species in cultivated and uncultivated areas in the regions of Rio Grande do Sul is not ruled out.

Supplementary Materials: The following are available online at http://www.mdpi.com/2073-4395/10/3/377/s1, Figure S1. Visualization of ${ }^{14} \mathrm{C}$-glyphosate in the GS and GR populations of $C$. distichophylla plants at 96 HAT. The highest concentration of ${ }^{14} \mathrm{C}$-glyphosate is highlighted in red. Arrows indicate the treated leaves.

Author Contributions: Conceptualization, J.G.V.-G. and R.D.P.; methodology, C.P.-B., H.E.C.-H., and A.M.R.-D.; software, J.G.V.-G., C.P.-B., and S.G.; validation, A.M.R.-D., H.E.C.-H., J.A.D.-V., and R.D.P.; formal analysis, H.E.C.-H., A.M.R.-D., and R.D.P.; investigation, J.G.V.-G.; resources, R.D.P.; data curation, J.G.V.-G., S.G. C.P.-B., and S.G.; writing-original draft preparation, J.G.V.-G., S.G., J.A.D.-V., and R.D.P.; writing-review and editing, J.G.V.-G., S.G., C.P.-B., A.M.R.-D., J.A.D.-V., and R.D.P.; visualization, R.D.P., J.G.V.-G., C.P.-B., A.M.R.-D., H.E.C.-H., S.G., and J.A.D.-V.; supervision, R.D.P.; project administration, R.D.P.; funding acquisition, R.D.P. All authors have read and agreed to the published version of the manuscript.

Funding: This work was funded by the Spanish Ministry of Economy and Competitiveness (AGL2016-78944-R) and the Asociación de Agroquímicos y Medioambiente.

Conflicts of Interest: The authors declare no conflict of interest.

\section{References}

1. Fleck, N.G.; Schaedler, C.E.; Agostinetto, D.; Rigoli, R.P.; Dal Magro, T.; Tironi, S.P. Associação de características de planta em cultivares de aveia com habilidade competitiva. Planta Daninha 2009, 27, 211-220. [CrossRef]

2. Kissmann, K.G. Plantas Infestantes e Nocivas|Instituto de Botânica, 2rd ed.; BASF Brasileira: São Paulo, Brazil, 1997; 825p.

3. Catasús Guerra, L.J. Las Gramíneas (Poaceae) de Cuba II, 1st ed.; Cavanillesia Altera: Madrid, Brazil, 2002.

4. Barkworth, M.E. Chloris Sw. In Manual of Grasses for North America; Barkworth, M.E., Anderton, L.K., Capels, K.M., Long, S., Piep, M.B., Eds.; Intermountain Herbarium and Utah State University Press: Logan, USA, 2007; pp. 185-253.

5. Cerros-Tlatilpa, R.; Siqueiros-Delgado, M.E.; Skendzic, E.M. El género Chloris Sw. (Poaceae: Chloridoideae) en México. Acta Bot. Mex. 2015, 112, 95-147. [CrossRef] 
6. Hoyos, V.; Mora, A.; Plaza, G.; De Prado, R. First report of Chloris radiata glyphosate resistance in Colombia. In Proceedings of the Sustainable Integrated Weed Management and Herbicide Tolerant Varieties, Thessaloniki, Greece, 4-6 July 2019; EWRS Working Groups: Salónica, Greece, 2019.

7. Nunes, A.L.; Vidal, R.A.; Trezzi, M.M. Herbicides to control Chloris distichophylla (False-Star-Grass). Rev. Bras. Herbic. 2007, 6, 13-21.

8. Moraes de Aguiar, A.C.; Cutti, L.; Orsolin da Silva, D.R.; Kaspary, T.E.; Muraro, D.S.; Rieder, E.; Gonsiorkiewicz Rigon, C.A. Avaliação de herbicidas para o controle de Chloris distichophylla. Agrotrópica 2017, 29, 69-74. [CrossRef]

9. Vencill, W.K.; Nichols, R.L.; Webster, T.M.; Soteres, J.K.; Mallory-Smith, C.; Burgos, N.R.; Johnson, W.G.; McClelland, M.R. Herbicide Resistance: Toward an Understanding of Resistance Development and the Impact of Herbicide-Resistant Crops. Weed Sci. 2012, 60, 2-30. [CrossRef]

10. Bracamonte, E.R.; Fernández-Moreno, P.T.; Bastida, F.; Osuna, M.D.; Alcántara-De La Cruz, R.; Cruz-Hipolito, H.E.; De Prado, R. Identifying Chloris species from cuban citrus orchards and determining their glyphosate-resistance status. Front. Plant Sci. 2017, 8, 1-11. [CrossRef]

11. Bracamonte, E.; da Silveira, H.M.; Alcántara-de la Cruz, R.; Domínguez-Valenzuela, J.A.; Cruz-Hipolito, H.E.; De Prado, R. From tolerance to resistance: Mechanisms governing the differential response to glyphosate in Chloris barbata. Pest Manag. Sci. 2018, 74, 1118-1124. [CrossRef]

12. Powles, S.B. Evolved glyphosate-resistant weeds around the world: Lessons to be learnt. Pest Manag. Sci. 2008, 64, 360-365. [CrossRef]

13. Baylis, A.D. Why glyphosate is a global herbicide: Strengths, weaknesses and prospects. Pest Manag. Sci. 2000, 56, 299-308. [CrossRef]

14. Duke, S.O.; Powles, S.B. Glyphosate: A once-in-a-century herbicide. Pest Manag. Sci. 2008, 64, 319-325. [CrossRef]

15. Duke, S.O. Glyphosate: The world's most successful herbicide under intense scientific scrutiny. Pest Manag. Sci. 2018, 74, 1025-1026. [CrossRef] [PubMed]

16. Steinrücken, H.C.; Amrhein, N. The herbicide glyphosate is a potent inhibitor of 5-enolpyruvylshikimic acid-3-phosphate synthase. Biochem. Biophys. Res. Commun. 1980, 94, 1207-1212. [CrossRef]

17. Maeda, H.; Dudareva, N. The Shikimate Pathway and Aromatic Amino Acid Biosynthesis in Plants. Annu. Rev. Plant Biol. 2012, 63, 73-105. [CrossRef]

18. HRAC Herbicide Resistant Action Committee. Available online: https://hracglobal.com/ (accessed on 28 February 2020).

19. Heap, I. Global perspective of herbicide-resistant weeds. Pest Manag. Sci. 2014, 70, 1306-1315. [CrossRef] [PubMed]

20. Sammons, R.D.; Gaines, T.A. Glyphosate resistance: State of knowledge. Pest Manag. Sci. 2014, 70, 1367-1377. [CrossRef] [PubMed]

21. Heap, I. International Survey of Herbicide Resistance Weed. Available online: http://www.weedscience.org/ Summary/MOA.aspx (accessed on 29 February 2020).

22. Ngo, T.D.; Malone, J.M.; Boutsalis, P.; Gill, G.; Preston, C. EPSPS gene amplification conferring resistance to glyphosate in windmill grass (Chloris truncata) in Australia. Pest Manag. Sci. 2018, 74, 1101-1108. [CrossRef] [PubMed]

23. Ngo, T.D.; Krishnan, M.; Boutsalis, P.; Gill, G.; Preston, C. Target-site mutations conferring resistance to glyphosate in feathertop Rhodes grass (Chloris virgata) populations in Australia. Pest Manag. Sci. 2017, 74, 1094-1100. [CrossRef]

24. Barroso, A.A.M.; Albrecht, A.J.P.; Dos Reis, F.C.; Placido, H.F.; Toledo, R.E.; Albrecht, L.P.; Filho, R.V. Different Glyphosate Susceptibility in Chloris polydactyla Accessions. Weed Technol. 2014, 28, 587-591. [CrossRef]

25. Brunharo, C.A.; Patterson, E.L.; Carrijo, D.R.; de Melo, M.S.; Nicolai, M.; Gaines, T.A.; Nissen, S.J.; Christoffoleti, P.J. Confirmation and mechanism of glyphosate resistance in tall windmill grass (Chloris elata) from Brazil. Pest Manag. Sci. 2016, 72, 1758-1764. [CrossRef]

26. Ge, X.; D’Avignon, D.A.; Ackerman, J.J.H.; Collavo, A.; Sattin, M.; Ostrander, E.L.; Hall, E.L.; Sammons, R.D.; Preston, C. Vacuolar Glyphosate-Sequestration Correlates with Glyphosate Resistance in Ryegrass (Lolium spp.) from Australia, South America, and Europe: A 31 P NMR Investigation. J. Agric. Food Chem. 2012, 60, 1243-1250. [CrossRef] 
27. Alcántara-de la Cruz, R.; Rojano-Delgado, A.M.; Giménez, M.J.; Cruz-Hipolito, H.E.; Domínguez-Valenzuela, J.A.; Barro, F.; De Prado, R. First Resistance Mechanisms Characterization in Glyphosate-Resistant Leptochloa virgata. Front. Plant Sci. 2016, 7, 1742. [CrossRef] [PubMed]

28. Malone, J.M.; Morran, S.; Shirley, N.; Boutsalis, P.; Preston, C. EPSPS gene amplification in glyphosate-resistant Bromus diandrus. Pest Manag. Sci. 2016, 72, 81-88. [CrossRef] [PubMed]

29. Shaner, D.L.; Nadler-Hassar, T.; Henry, W.B.; Koger, C.H. A rapid in vivo shikimate accumulation assay with excised leaf discs. Weed Sci. 2005, 53, 769-774. [CrossRef]

30. Rojano-Delgado, A.M.; Ruiz-Jiménez, J.; de Castro, M.D.L.; De Prado, R. Determination of glyphosate and its metabolites in plant material by reversed-polarity CE with indirect absorptiometric detection. Electrophoresis 2010, 31, 1423-1430. [CrossRef]

31. de Carvalho, L.B.; Alves, P.L.D.C.A.; González-Torralva, F.; Cruz-Hipolito, H.E.; Rojano-Delgado, A.M.; De Prado, R.; Gil-Humanes, J.; Barro, F.; Luque de Castro, M.D. Pool of Resistance Mechanisms to Glyphosate in Digitaria insularis. J. Agric. Food Chem. 2012, 60, 615-622. [CrossRef]

32. Rojano-Delgado, A.M.; Cruz-Hipolito, H.; De Prado, R.; Luque de Castro, M.D.; Franco, A.R. Limited uptake, translocation and enhanced metabolic degradation contribute to glyphosate tolerance in Mucuna pruriens var. utilis plants. Phytochemistry 2012, 73, 34-41. [CrossRef]

33. Ritz, C.; Baty, F.; Streibig, J.C.; Gerhard, D. Dose-Response Analysis Using R. PLoS ONE 2015, 10 , e0146021. [CrossRef]

34. R Core Team. R: A Language and Environment for Statistical Computing. Available online: https://www.r-project.org/ (accessed on 28 February 2020).

35. Christoffoleti, P.J.; Galli, A.J.; Carvalho, S.J.; Moreira, M.S.; Nicolai, M.; Foloni, L.L.; Martins, B.A.; Ribeiro, D.N. Glyphosate sustainability in South American cropping systems. Pest Manag. Sci. 2008, 64, 422-427. [CrossRef]

36. Powles, S.B.; Lorraine-Colwill, D.F.; Dellow, J.J.; Preston, C. Evolved resistance to glyphosate in rigid ryegrass (Lolium rigidum) in Australia. Weed Sci. 1998, 46, 604-607. [CrossRef]

37. Khan, I.M.; Hassan, G.; Khan, I.; Marwat, K.B. Testing of herbicides at various doses on the growth stages of wild onion grown in pots. Sarhad J. Agric. 2011, 27, 85-91.

38. Preston, C.; Wakelin, A.M. Resistance to glyphosate from altered herbicide translocation patterns. Pest Manag. Sci. 2008, 64, 372-376. [CrossRef] [PubMed]

39. Vila-Aiub, M.M.; Balbi, M.C.; Distéfano, A.J.; Fernández, L.; Hopp, E.; Yu, Q.; Powles, S.B. Glyphosate resistance in perennial Sorghum halepense (Johnsongrass), endowed by reduced glyphosate translocation and leaf uptake. Pest Manag. Sci. 2012, 68, 430-436. [CrossRef] [PubMed]

40. Duke, S.O. Glyphosate Degradation in Glyphosate-Resistant and -Susceptible Crops and Weeds. J. Agric. Food Chem. 2011, 59, 5835-5841. [CrossRef] [PubMed]

41. Alcántara-de la Cruz, R.; Fernández-Moreno, P.T.; Ozuna, C.V.; Rojano-Delgado, A.M.; Cruz-Hipolito, H.E.; Domínguez-Valenzuela, J.A.; Barro, F.; De Prado, R. Target and Non-target Site Mechanisms Developed by Glyphosate-Resistant Hairy beggarticks (Bidens pilosa L.) Populations from Mexico. Front. Plant Sci. 2016, 7, 1492. [CrossRef] [PubMed]

42. Pan, L.; Yu, Q.; Han, H.; Mao, L.; Nyporko, A.; Fan, L.; Bai, L.; Powles, S. Aldo-keto Reductase Metabolizes Glyphosate and Confers Glyphosate Resistance in Echinochloa colona. Plant Physiol. 2019, 181, 1519-1534. [CrossRef] [PubMed]

43. Alcántara de la Cruz, R.; Barro, F.; Domínguez-Valenzuela, J.A.; De Prado, R. Physiological, morphological and biochemical studies of glyphosate tolerance in Mexican Cologania (Cologania broussonetii (Balb.) DC.). Plant Physiol. Biochem. 2016, 98, 72-80. [CrossRef]

44. Ribeiro, D.N.; Nandula, V.K.; Dayan, F.E.; Rimando, A.M.; Duke, S.O.; Reddy, K.N.; Shaw, D.R. Possible Glyphosate Tolerance Mechanism in Pitted Morningglory (Ipomoea lacunosa L.). J. Agric. Food Chem. 2015, 63, 1689-1697. [CrossRef]

45. González-Torralva, F.; Rojano-Delgado, A.M.; Luque de Castro, M.D.; Mülleder, N.; De Prado, R. Two non-target mechanisms are involved in glyphosate-resistant horseweed (Conyza canadensis L. Cronq.) biotypes. J. Plant Physiol. 2012, 169, 1673-1679. [CrossRef]

46. Bracamonte, E.; Fernández-Moreno, P.T.; Barro, F.; De Prado, R. Glyphosate-Resistant Parthenium hysterophorus in the Caribbean Islands: Non Target Site Resistance and Target Site Resistance in Relation to Resistance Levels. Front. Plant Sci. 2016, 7, 1845. [CrossRef] 
47. García, M.J.; Palma-Bautista, C.; Rojano-Delgado, A.M.; Bracamonte, E.; Portugal, J.; Alcántara-de la Cruz, R.; De Prado, R. The Triple Amino Acid Substitution TAP-IVS in the EPSPS Gene Confers High Glyphosate Resistance to the Superweed Amaranthus hybridus. Int. J. Mol. Sci. 2019, 20, 2396. [CrossRef]

48. Christoffoleti, P.; Trentin, R.; Tocchetto, S.; Marochi, A.; Galli, A.J.; López-Ovejero, R.; Nicolai, M. Alternative Herbicides to Manage Italian Ryegrass (Lolium multiflorum Lam) Resistant to Glyphosate at Different Phenological Stages. J. Environ. Sci. Health Part B 2005, 40, 59-67. [CrossRef] [PubMed]

49. Davidson, B.; Cook, T.; Chauhan, B.S. Alternative Options to Glyphosate for Control of Large Echinochloa colona and Chloris virgata Plants in Cropping Fallows. Plants 2019, 8, 245. [CrossRef] [PubMed]

50. Alcántara-de la Cruz, R.; Moraes de Oliveira, G.; Bianco de Carvalho, L.; Fátima das Graças Fernandes da Silva, M. Herbicide Resistance in Brazil: Status, Impacts, and Future Challenges. In Herbicides—Current Research and Case Studies in Use, 2nd ed.; Ferreira, K.M., Ed.; IntechOpen (in Press): Rijeka, Croatia, 2020; pp. 1-25.

(C) 2020 by the authors. Licensee MDPI, Basel, Switzerland. This article is an open access article distributed under the terms and conditions of the Creative Commons Attribution (CC BY) license (http://creativecommons.org/licenses/by/4.0/). 